\title{
Analisis Eksistensi Platform Bukadagang
}

\author{
Platform Existence Analysis of Bukadagang
}

\author{
Muhammad Azmi**1, Wahyu Nugraha ${ }^{2}$, Muhamad Nur ${ }^{3}$, Brama Wahyu Prabowo 4 , \\ Amirudin Khorul Huda ${ }^{5}$, Tanjung Surya Puruhita ${ }^{6}$, Ahmad Rifki Harir ${ }^{7}$ \\ ${ }^{1}$ STMIK Syaikh Zainuddin NW Anjanni, \\ 2, 3, 4, 5, 6, 7 Magister Teknik Informatika Universitas Amikom Yogyakarta \\ E-mail: *1muhammad4zmi@gmail.com, ${ }^{2}$ wahyu.1104@students.amikom.ac.id \\ ${ }^{3}$ students.nurmuhamad@gmail.com, ${ }^{4}$ bramaprabowo647@gmail.com, \\ 5amirudinkhorulhuda@gmail.com, ${ }^{6}$ tanjungsurya@gmail.com, \\ 7ahmad.1105@students.amikom.ac.id
}

\begin{abstract}
Abstrak
Pertumbuhan E-Commerce di indonesia semakin berkembang dengan cepat, maka dibutuhkan sebuah platform E-Commerce yang mampu memenuhi kebutuhan masyarakat. Platform Bukadagang merupakan salah satu online marketplace yang menyediakan sarana jualbeli dari konsumen ke konsumen. Pengguna perorangan ataupun perusahaan dapat membeli dan menjual semua jenis produk, produk baru maupun bekas. Persaingan e-commerce di Indonesia semakin hari semakin menarik, oleh sebab itu para penggiat e-commerce harus terus berinovasi untuk menghindari disrupsi teknologi, sehingga untuk menjaga eksistensi Bukadagang dalam ekosistem teknologi e-commerce maka diperlukan untuk melakukan analisis faktor-faktor yang menyebabkan eksistensinya tetap terjaga, dan menyebabkan masyarakat semakin tertarik untuk berbisnis dan bertransaksi di Bukadagang. Bukadagang memiliki tiga faktor utama yang mempengaruhi eksistensinya ditengah persaingan Platform-Platform E-Commerce saat ini, yaitu Produk Populer, Penjual Terajin dan Diskon dapat memberikan gambaran bagaimana sistem pada Platform Bukadagang bekerja, baik dari sisi aturan-aturan atau rule-rule di setiap item maupun dari sisi perancangan dan pemanfaatan databasenya.
\end{abstract}

Kata Kunci-E-Commerce, Bukadagang, Eksistensi, Platform

\section{Abstract}

The growth of E-Commerce and digital economy in Indonesia is growing and The growth of E-Commerce in Indonesia is growing rapidly, it requires an E-Commerce platform that is able to meet people's needs. The Bukadagang platform is one of the online marketplaces that provides a means of buying and selling from consumers to consumers. Individual users or companies can buy and sell all types of products, new and used products. Competition in e-commerce in Indonesia is increasingly attractive, therefore e-commerce activists must continue to innovate to avoid technological disruption, so that to maintain the existence of Bukadagang in the ecommerce technology ecosystem it is necessary to analyze the factors that cause its existence to remain maintained, and caused people to be more interested in doing business and transacting at Bukadagang. Bukadagang has three main factors that influence its existence in the midst of competition E-Commerce Platforms today, namely Popular Products, Promised Sellers and Discounts can give an idea of how the system on the Bukadagang Platform works, both in terms of rules or rules in each item and from the design and utilization of the database.

Keywords - E-Commerce, Bukadagang, Factor, Platform 


\section{PENDAHULUAN}

Penggunaan internet sebagai media perdagangan terus meningkat dari tahun ke tahun, hal ini sangat mempengaruhi perkembangan dan pertumbuhan ekonomi digital. Berbagai manfaat akan didapat oleh perusahaan maupun konsumen dengan melakukan transaksi melalui internet. Perusahaan-perusahaan di Indonesia mulai membangun platform-platform e commerce.

Dengan adanya Platform E-Commerce kita semakin dimudahkan dalam melakukan transaksi karena tidak lagi membutuhkan tenaga dan waktu yang lama untuk mencari barang yang kita butuhkan. Karena esensi dari e-commerce adalah memungkinkan proses jual beli tidak terhalang oleh jarak dan waktu.

Sebuah laporan bertajuk Unlocking Indonesia's Digital Opportunity yang diusung oleh McKinsey pada tahun 2017 menyatakan peralihan ke ranah digital akan meningkatkan pertumbuhan ekonomi hingga US\$ 150 miliar dolar pada 2025. Sekitar 73 persen pengguna internet di Indonesia mengakses internet melalui perangkat selular dan akan terus terus bertambah dalam lima tahun ke depan. Berdasarkan data e-marketer tahun 2013 yang dilansir dari situs Top Brand-Award, jumlah pengguna internet di Indonesia yang melakukan transaksi melalui Platform e-commerce mencapai angka 4,6 juta, sedangkan total transaksi mencapai US $\$ 1,8$ juta atau sekitar Rp. 21,9 triliun dan terus bertambah setiap tahunnya. Data Sensus Ekonomi 2016 juga menyatakan bahwa e-commerce Indonesia akan terus tumbuh sekitar $17 \%$ dalam 10 tahun terakhir dengan total sekitar 26,2 juta usaha [1].

Pertumbuhan E-Commerce dan ekonomi digital di Indonesia semakin berkembang dan semakin cepat, maka dibutuhkan sebuah platform E-Commerce yang mampu memenuhi kebutuhan masyarakat pada saat ini. Platform Bukadagang merupakan salah satu online marketplace yang menyediakan sarana jual-beli dari konsumen ke konsumen. Semua orang dapat membuka toko online di Platform Bukadagang dan melayani pembeli dari seluruh Indonesia untuk transaksi satuan maupun banyak. Pengguna perorangan ataupun perusahaan dapat membeli dan menjual produk baru maupun bekas, seperti perlengkapan rumah tangga, perlengkapan kantor, perlengkapan olahraga, gadget, komputer, dan sebagainya.

Dalam membuat dan merancang sebuah sistem perangkat lunak yang dapat memenuhi kebutuhan pengguna jelas bukan merupakan persoalan yang mudah. Kebutuhan pengguna yang sangat bervariasi dengan mekanisme dan perilaku yang berbeda membutuhkan kesesuaian, konsistensi dan sinkronisasi informasi. Sebuah sistem tidak hanya fokus kepada model dan fiturfitur dari sebuah perangkat lunak serta bahasa pemrograman dan penggunaan basis datanya [2]. Sehingga Platform Bukadagang hadir sebagai solusi alternatif untuk sistem E-Commerce.

Persaingan e-commerce di Indonesia semakin hari semakin menarik, oleh sebab itu para penggiat e-commerce harus terus berinovasi untuk menghindari distrupsi teknologi, dengan semakin banyaknya persaingan maka Platform Bukadagang harus berinovasi dan menawarkan sesuatu yang berbeda dengan ecommerce yang sudah terlebih dahulu eksis.

Sehingga untuk menjaga eksistensi Platform Bukadagang dalam ekosistem teknologi ecommerce maka diperlukan melakukan analisis terhadap faktor-faktor yang menyebabkan eksistensinya tetap terjaga, dan menyebabkan masyarakat semakin tertarik untuk berbisnis dan bertransaksi di Bukadagang.

\section{METODE PENELITIAN}

\subsection{Tinjauan Pustaka}

\subsubsection{E-Commerce}

E-Commerce adalah suatu jenis dari mekanisme bisnis secara elektronis yang memfokuskan diri pada transaksi bisnis berbasis individu dengan menggunakan internet sebagai 
medium pertukaran barang atau jasa baik antara dua buah institusi (B-to-B) maupun antara institusi dan konsumen langsung (B-to-C) [3].

E-Commerce merupakan bagian dari E-Bussiness, dimana cakupan e-bussiness lebih luas, tidak hanya sekedar perniagaan tetapi mencakup juga pengkolaborasian mitra bisnis, pelayanan nasabah, lowongan pekerjaan dan lain-lain. Selain teknologi jaringan www, e-commerce juga memerlukan teknologi basis data atau pangkalan data (database), e-surat atau surat elektronik (email), dan bentuk teknologi non komputer yang lain seperti halnya sistem pengiriman barang, dan alat pembayaran untuk e-commerce ini [4].

\subsubsection{Eksistensi}

Menurut Abidin Zaenal eksistensi merupakan suatu proses yang dinamis, suatu, menjadi atau mengada. Ini sesuai dengan asal kata eksistensi itu sendiri, yakni exsistere, yang artinya keluar dari, melampaui atau mengatasi. Jadi eksistensi tidak bersifat kaku dan terhenti, melainkan lentur atau kenyal dan mengalami perkembangan atau sebaliknya kemunduran, tergantung pada kemampuan dalam mengaktualisasikan potensi - potensinya [5]. Eksistensi dalam tulisan ini memiliki arti yang berbeda, eksistensi yang dimaksud adalah keberadaan suatu platform yang akan tetap bertahan dalam perkembangan $e$-commerce. Eksistensi yang dimaksud adalah dalam online marketplace.

\subsubsection{Palform E-Commerce}

Platform e-commerce adalah solusi teknologi perangkat lunak atau software untuk membangun storefronts. Storefronts merupakan skema bisnis yang berkaitan dengan penjualan produk atau layanan [6].

\subsection{Jenis Penelitian}

Menurut Arikunto penelitian deskriptif tidak dimaksudkan untuk menguji hipotesis tetapi hanya menggambarkan apa adanya gejala, keadaan atau fakta [7]. Sedangkan penelitian kualitatif adalah metode penelitian yang berlandaskan pada filsafat postpositivitisme, digunakan untuk meneliti pada kondisi obyek yang alamiah, sebagai lawannya adalah eksperimen dimana peneliti adalah instrumen kunci, teknik pengumpulan data dilakukan secara triangular (gabungan), analisis data bersifat induktif/kualitatif, dan hasil penelitian kualitatif lebih menekankan makna pada generalisasi [8].

Jadi, bisa disimpulkan bahwa penelitian ini menggunakan metode kualitatif deskriptif yang bertujuan memberikan solusi kepada pemakai sistem dalam hal mendesain dan membuat prototype sistem e-commerce untuk memperluas pemasaran.

\subsection{Fokus Penelitian Analisis}

Penentuan fokus penelitian sangat menentukan langkah-langkah penelitian, sebab fokus merupakan tahap awal permulaan yang dipilih sebagai wilayah umum ditahap pertama pelaksanaan penelitian, sehingga penelitian memperoleh gambaran umum, secara menyeluruh tentang sunyek atau situasi yang diteliti [9]. Sesuai dengan judul penelitian, maka fokus dalam penelitian ini adalah sebagai berikut:

\subsubsection{Gambaran umum Bukadagang}

Bukadagang merupakan salah satu online marketplace yang menyediakan sarana jual beli dari konsumen ke konsumen. Semua orang dapat membuka toko online di Bukadagang dan melayani pembeli dari seluruh Indonesia untuk transaksi satuan maupun banyak. Pengguna perorangan ataupun perusahaan dapat membeli dan menjual produk, produk baru maupun bekas, seperti perlengkapan rumah tangga, perlengkapan kantor, perlengkapan olahraga, gadget, komputer, dan sebagainya. 
Dalam sistem Bukadagang sendiri nantinya akan beritegrasi dengan sistem lainnya untuk memperoleh beberapa data yang dibutuhkan, dimana model komunikasinya dengan menggunakan API (Application Programming Interface). Artinya dalam sistem Bukadagang akan hidup aplikasi-aplikasi lain yang saling berintegrasi, ilustrasi model integrasi data yang ada di dalam sistem Bukadagang seperti ditunjukkan pada gambar 1.

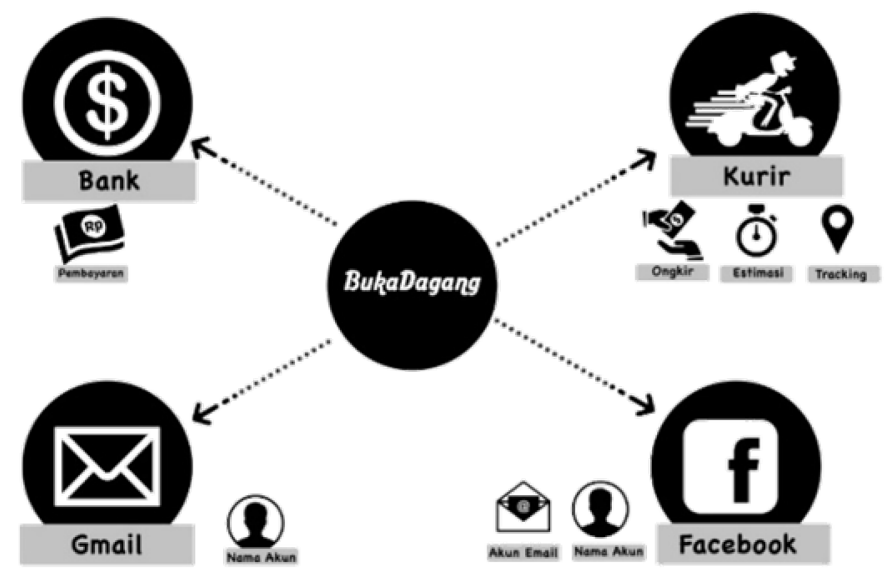

Gambar 1. Integrasi Sistem Bukadagang

\subsubsection{Analisis faktor-faktor yang mempengaruhi eksistensi Bukadagang}

Pada bagian ini akan dilakukan pembahasan terhadap faktor-faktor yang mempengaruhi atau yang membesarkan Bukadagang, Bukadagang sendiri memiliki 3 (tiga) faktor utama yang akan membesarkan Bukadagang. Dimana faktor-faktor tersebut akan menjadi ciri khas tersendiri Bukadagang.

a. Produk Populer

Sebuah produk dikatakan sebagai produk populer apabila memenuhi syarat regulasi yang dibuat Bukadagang sebagai berikut:

a) Jumlah Barang yang Terjual dengan minimal penjualan 300 produk

b) Viewer ( Barang Sering di lihat ) dengan minimal viewer 300

c) Barang di Favorit kan dan difavoritkan minimal 300 calon pembeli

d) Feedback (Rating) dengan rating rata-rata minimal nilai 4

e) Ulasan Barang akan dikategorikan berdasarkan persentase dari jumlah ulasan positif yang diberikan oleh calon pembeli

b. Penjual Terajin

Dimana dikatakan sebagai penjual terajin apabila memenuhi kriteria sebagai berikut:

a) Sering Jual Produk, yang menjadi parameternya adalah jumlah postingan produk

b) Responsif, (Cepat membalas chat dan respon cepat terhadap pesanan)

c. Diskon

Diskon merupakan bentuk promosi yang diberikan penjual untuk menarik minat belanja calon pembeli terhadap produk-produk yang ditawarkan, dalam sistem Bukadagang sendiri kriteria diskon sebagai berikut:

a) Diskon Kuantitas; diberikan setiap minggu atau setiap bulan untuk meningkatkan minat pembeli untuk melakukan transaksi

b) Diskon Musiman; diberikan pada hari raya dan tahun baru

\subsubsection{Desain interface dan Query SQL yang berjalan dibalik sistem}

Pada bagian ini akan dibahas bagaimana rule-rule penentuan item-item Produk Populer, Penjual Terajin dan Diskon dan bentuk Query dan Rancangan Desain Interface nya. 


\section{HASIL DAN PEMBAHASAN}

Pada analisis ini di mulai dengan merancang databasenya terlebih dahulu, sebagai bagian terpenting dalam membangun sebuah sistem, dalam merancang sebuah database maka perlu diperhatikan unsur- unsur utama yang wajib ada dalam sebuah database, meliputi Primary Key. Primary key sendiri merupakan satu atau lebih nilai pada kolom untuk membuat sebuah record unik dan penggunaan Foreign key ke semua table yang berelasi. foreign key berguna untuk menjamin integritas referensial dan untuk memastikan nilai pada suatu kolom (atau kumpulan kolom) sesuai dengan nilai yang ada pada tabel lain dan penggunaan constrains- constrains yang lainnya. Sehingga untuk membangun sistem Bukadagang dibuatlah desain rancangan database nya seperti pada Gambar 2 sampai Gambar 5.

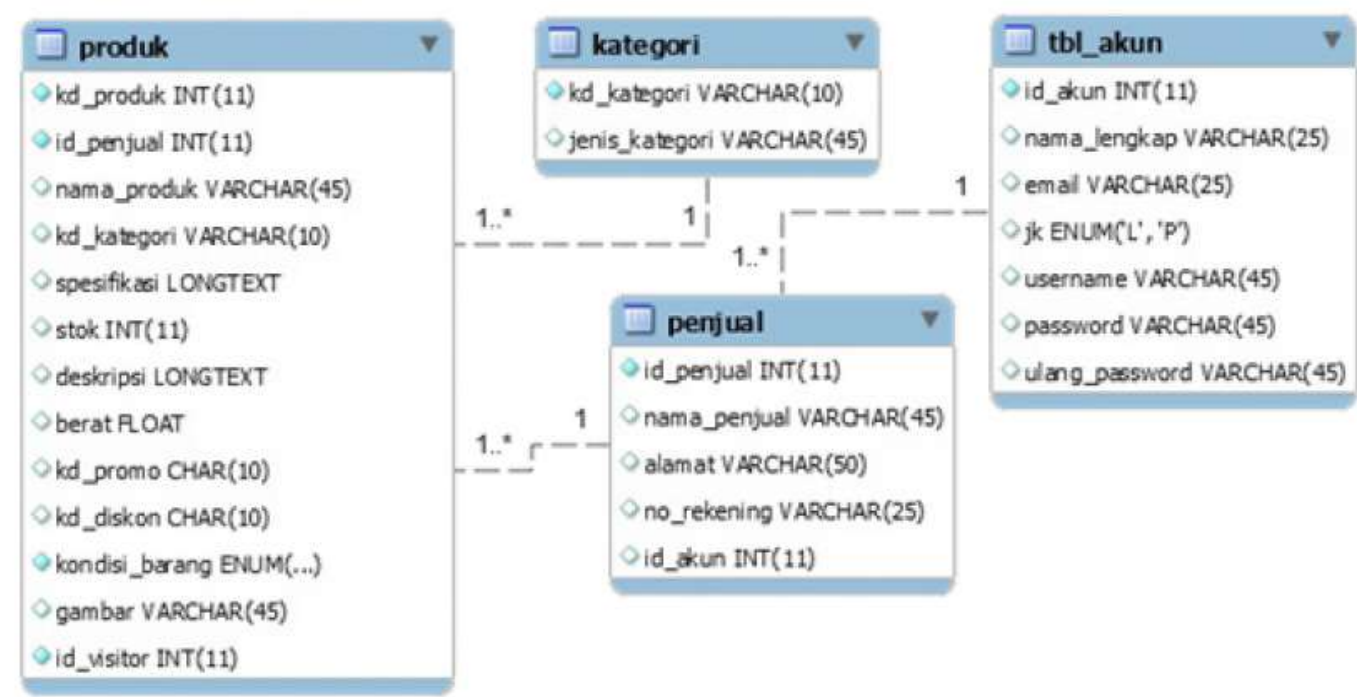

Gambar 2. Rancangan Struktur Database (Bagian 1)

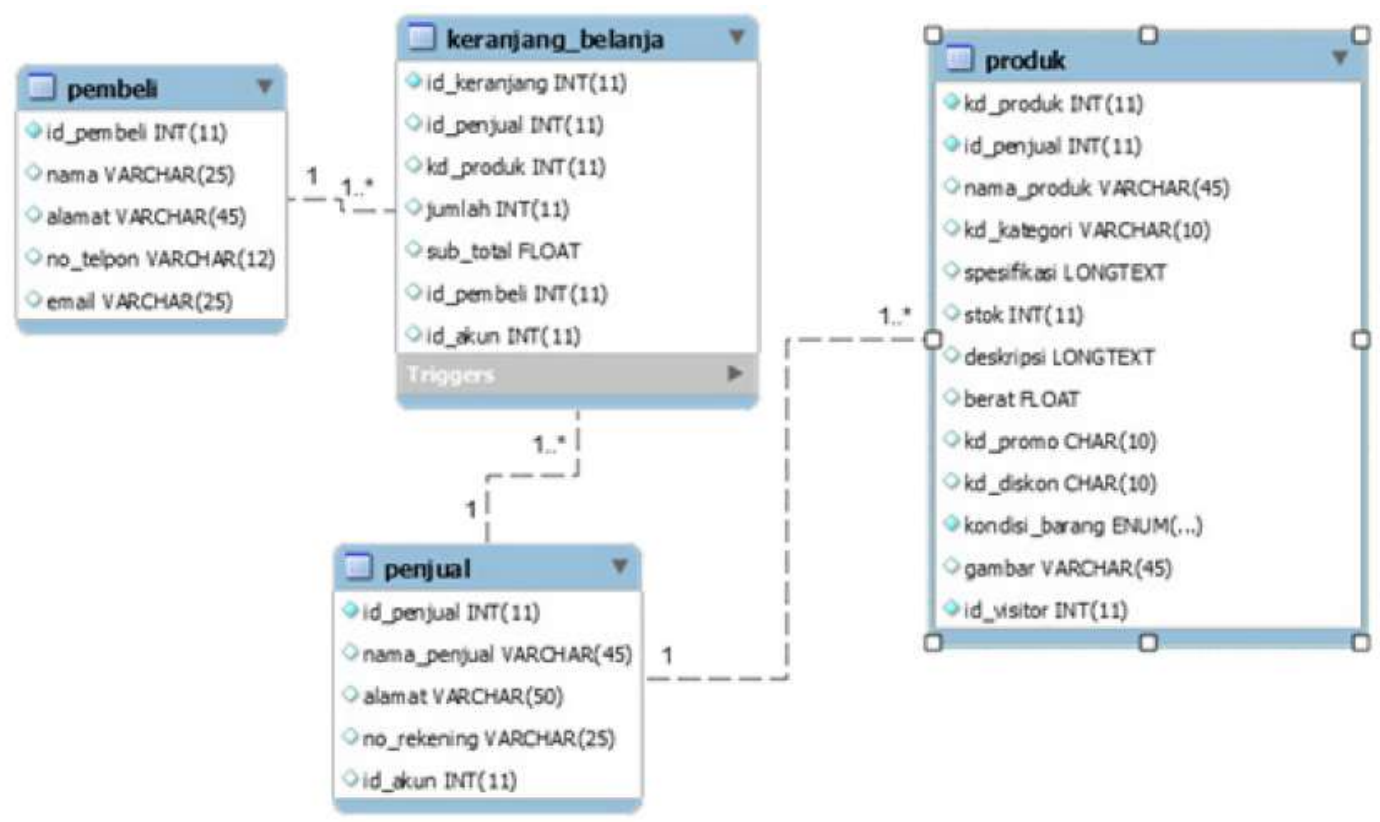

Gambar 3. Rancangan Struktur Database (Bagian II) 


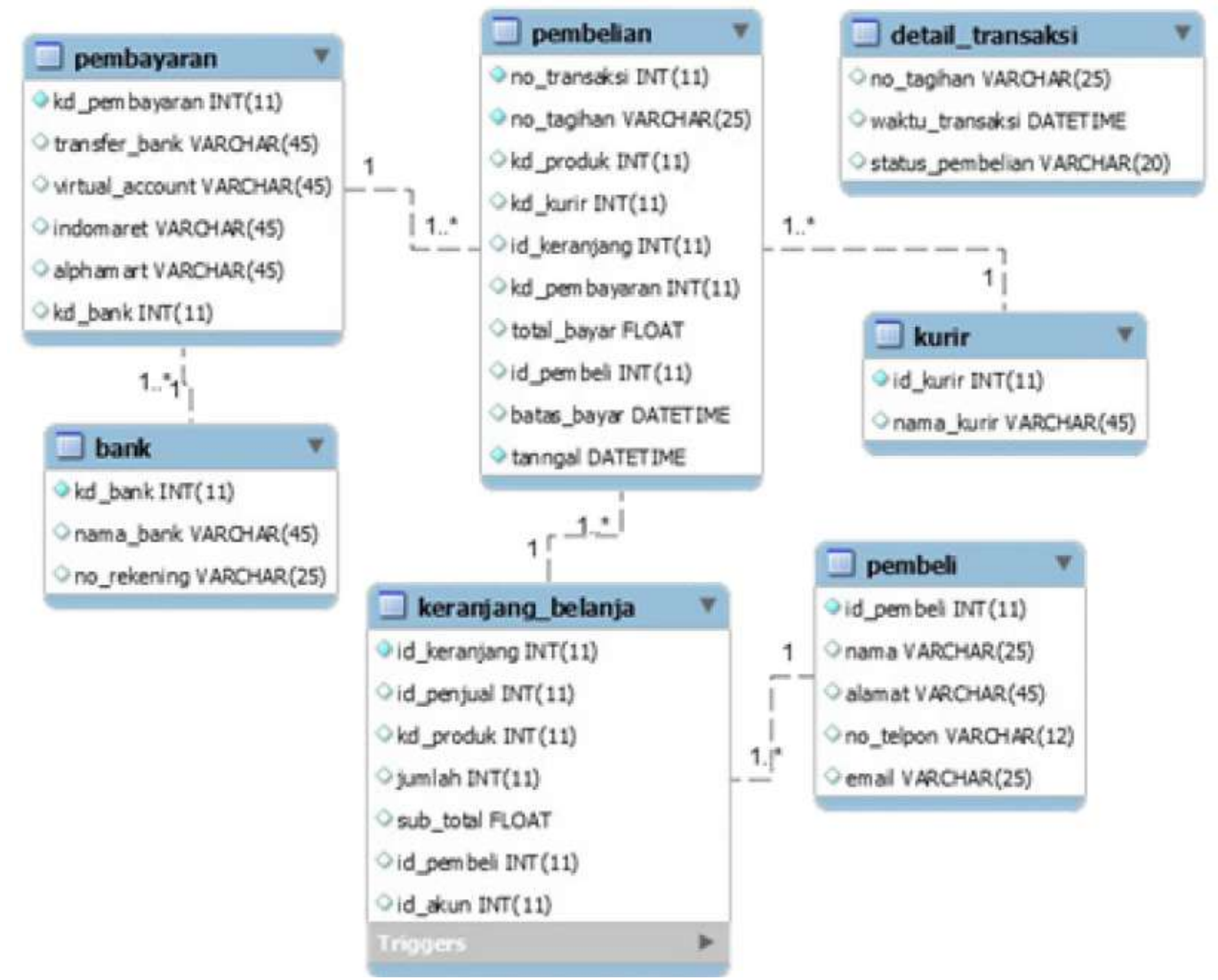

Gambar 4. Rancangan Struktur Database (Bagian III)

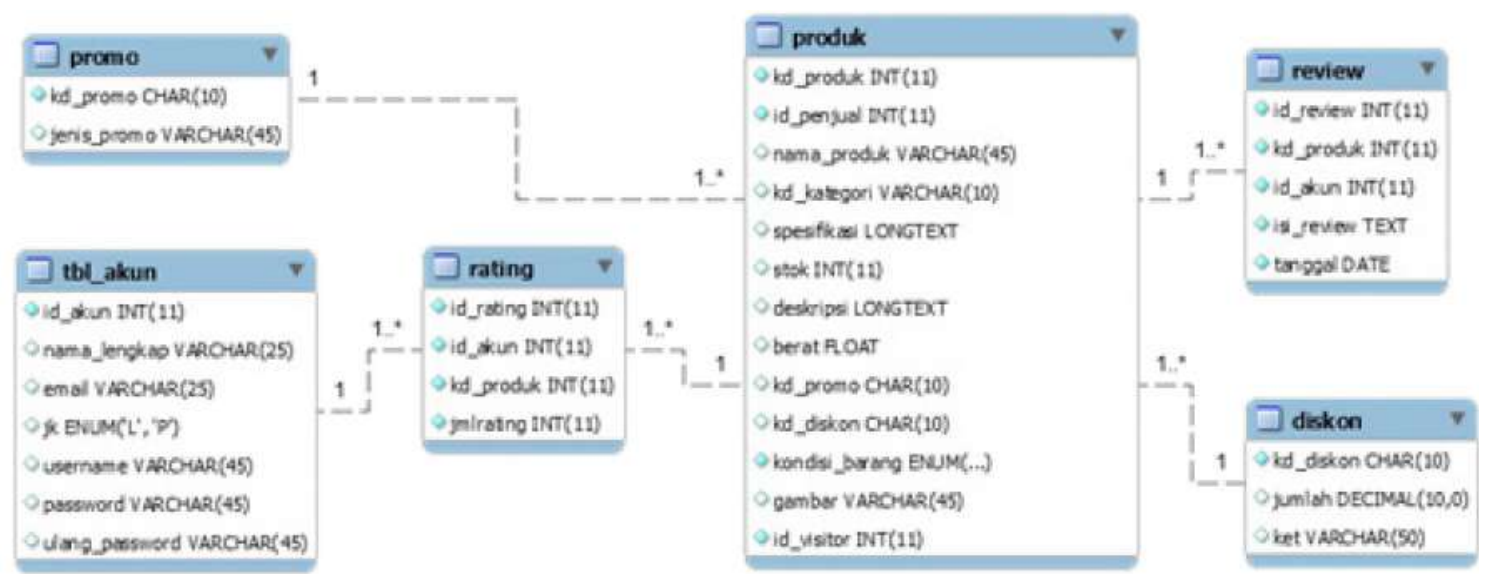

Gambar 5. Rancangan Struktur Database (Bagian IV)

Kemudian akan dilakukan tahapan Desain interface dan penggunaan Query SQL untuk setiap Rancangan Interface terhadap tiga Item yang menjadi faktor yang menentukan eksistensi Platform Bukadang.

\subsection{Produk Populer}

Penentuan produk populer sistem Bukadagang menentukan aturan barang harus terjual minimal 300 item, viewer barang minimal 300, difavoritkan oleh calon pembeli sebanyak 300 , pemberian feedback atau rating minimal 4 dan jumlah pemberian ulasan positif terhadap produk tersebut. Untuk menerapakan aturan tersebut sistem Bukadagang akan mengakses sebanyak 7 (tujuh) buah tabel, yaitu tabel produk, rating, review, viewer, whislist atau favorit, dan tabel 
penjual. dan mengeksekusi 4 (empat) buah view yaitu view rating, view produk_terjual, view review dan view viewer produk untuk bisa menentukan sebuah produk bisa dikatan populer.

Gambar 6 dan Gambar 7 menunjukkan bagaimana sebuah produk bisa dikatakan sebagai produk Populer.
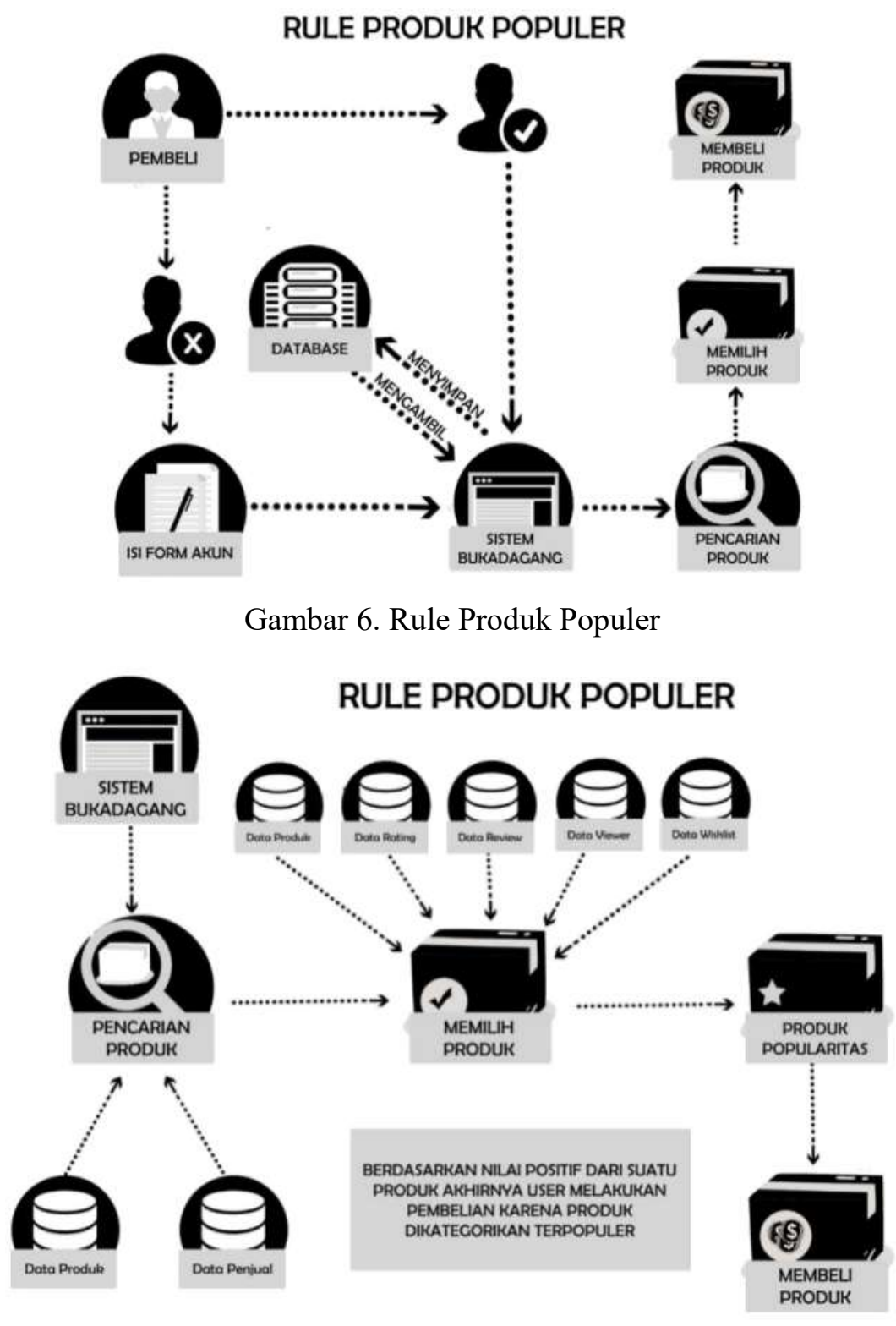

Gambar 7. Rule Produk Populer

Rule produk populer adalah visualisasi dari alur penetuan produk dikatakan populer, adapun tabel yang berperan sebagai berikut:

1) Dalam proses pencarian produk tabel yang berperan adalah tabel produk, tabel penjual.

2) Saat memilih produk tabel yang berperan adalah tabel produk, tabel rating, tabel review, tabel viewer, tabel whislist.

Selanjutnya untuk query penentuan sebuah produk populer, maka harus dibuatkan viewview dalam perintah $S Q L$ yang nantinya akan menjadi penentu sebuah produk dikatakan populer, berikut query-query $S Q L$ yang berperan untuk menentukan produk populer: 
a) View Rating merupakan sebuah perintah Query $S Q L$ yang dibuat untuk mengekseskusi rating sebuah produk dengan melakukan perintah SUM (menjumlahkan) pada sebuah field bernama jmlrating kemudian dibagi dengan jumlah akun yang melakukan rating sebuah produk. Berikut perintah Query $S Q L$ nya.

SELECT kd_produk, SUM(jmlrating)/COUNT(id_akun) AS jml_rating EROM rating WHERE kd_produk=1;

b) View Produk Terjual merupakan Query $S Q L$ yang dibuat untuk menentukan jumlah terjual sebuah produk dengan mengeksekusi tabel produk dan keranjang_belanja untuk mendapatkan jumlah terjual suatu produk. Berikut Query $S Q L$ nya.

\section{SELECT}

produk.kd_produk,produk.nama_produk, keranjang_belanja.id_penjual, SUM ( keranj ang_belanja.jumlah)AS terjual FROM produk, keranjang_belanja WHERE produk.kd_produk='1' AND keranjang_belanja.id_penjual=101;

c) View Review merupakan Query $S Q L$ yang dibuat untuk menentukan review atau berapa banyak orang yang memberikan komentar dari suatu produk, dimana View ini mengakses atau mengeksekusi tabel review dengan perintah SQL sebagai berikut:

$\underline{\text { SELECT }}$ count(id_akun) AS total_review FROM review WHERE kd_produk=1;

d) View Viewer Produk merupakan Query SQL yang dibuat untuk melihat berapa banyak jumlah calon pembeli yang melihat suatu produk, pada View ini mengakses table visitor dengan perintah SQL sebagai berikut:

SELECT SUM (counter) AS viewer EROM visitor WHERE kd_produk=1;

e) Query ini akan mengeksekusi semua view yang sudah dibuat sebelumnya untuk menentukan sebuah produk masuk dalam kategori Produk Populer, dimana Query ini mengimplementasikan semua rule atau aturan yang sudah dibuat sebelumnya dalam menentukan Produk Populer.

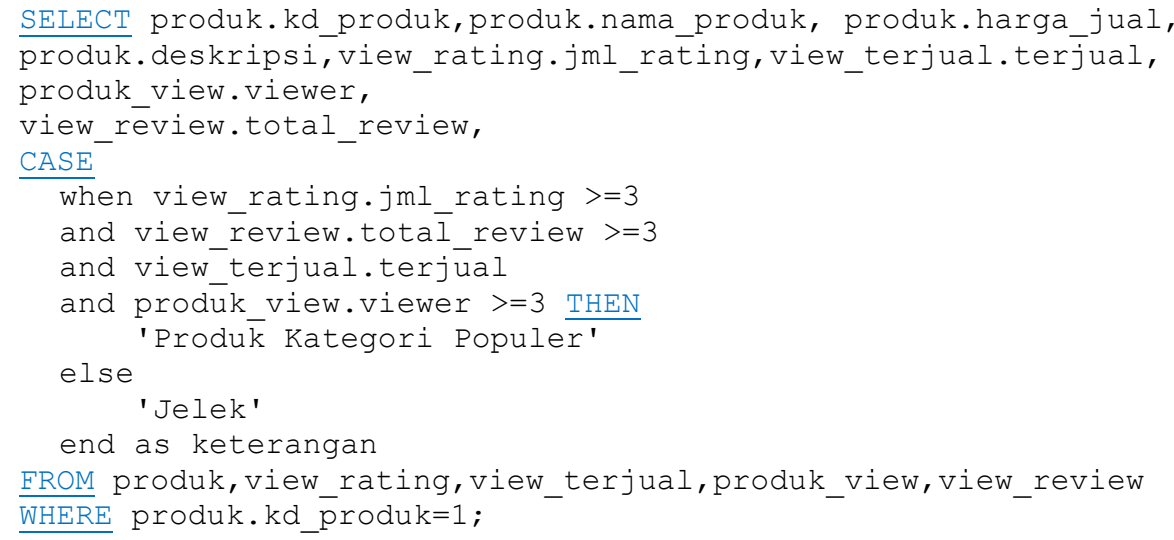

Tampilan hasil Query produk terpopuler terlihat pada Gambar 8. Visualisasi dalam sebuah rancangan Interface ditampilkan pada Gambar 9.

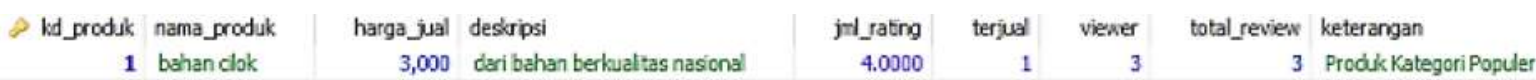

Gambar 8. Hasil Query Produk Populer 
Citec Journal, Vol. 5, No. 3, Mei 2018 - Juli 2018
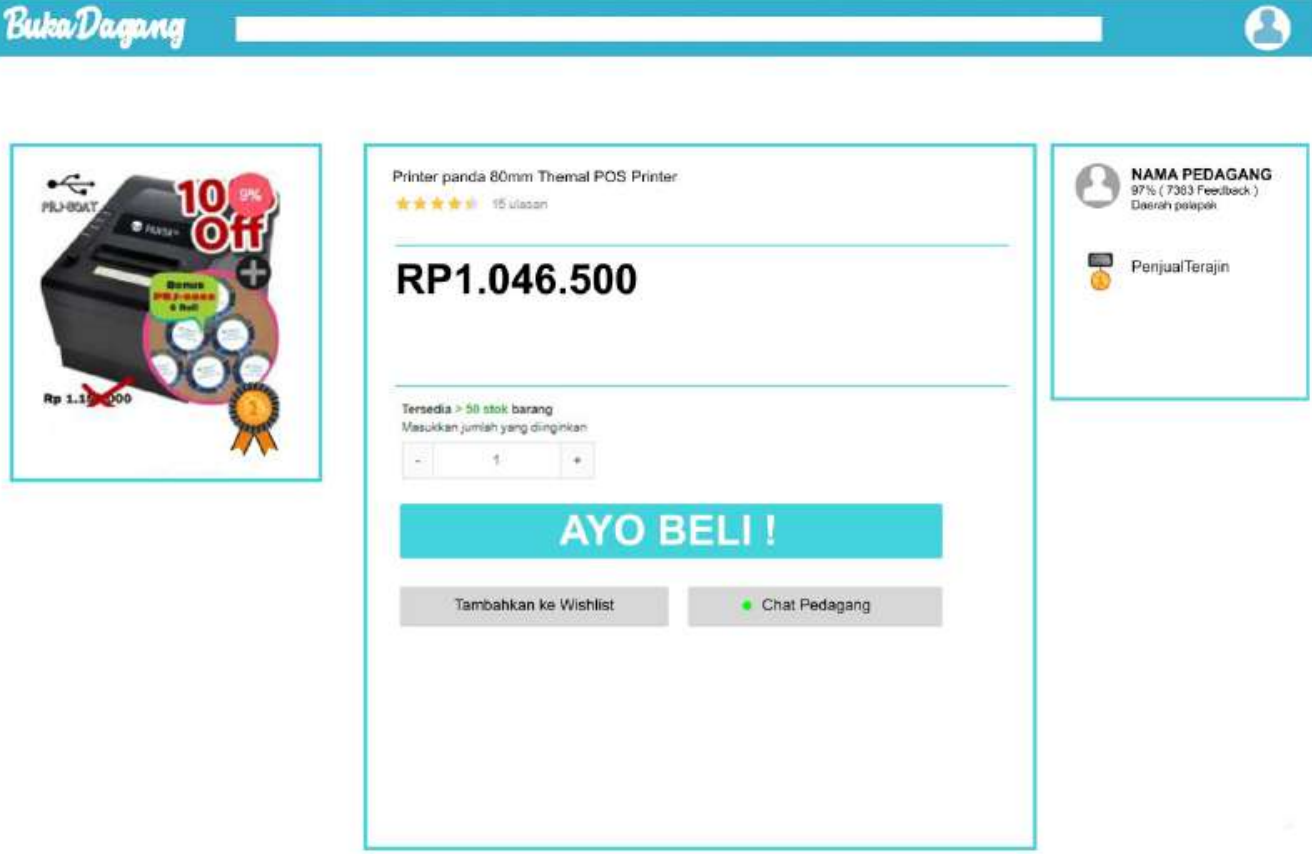

Gambar 9. Desain Interface Produk Populer

\subsection{Penjual Terajin}

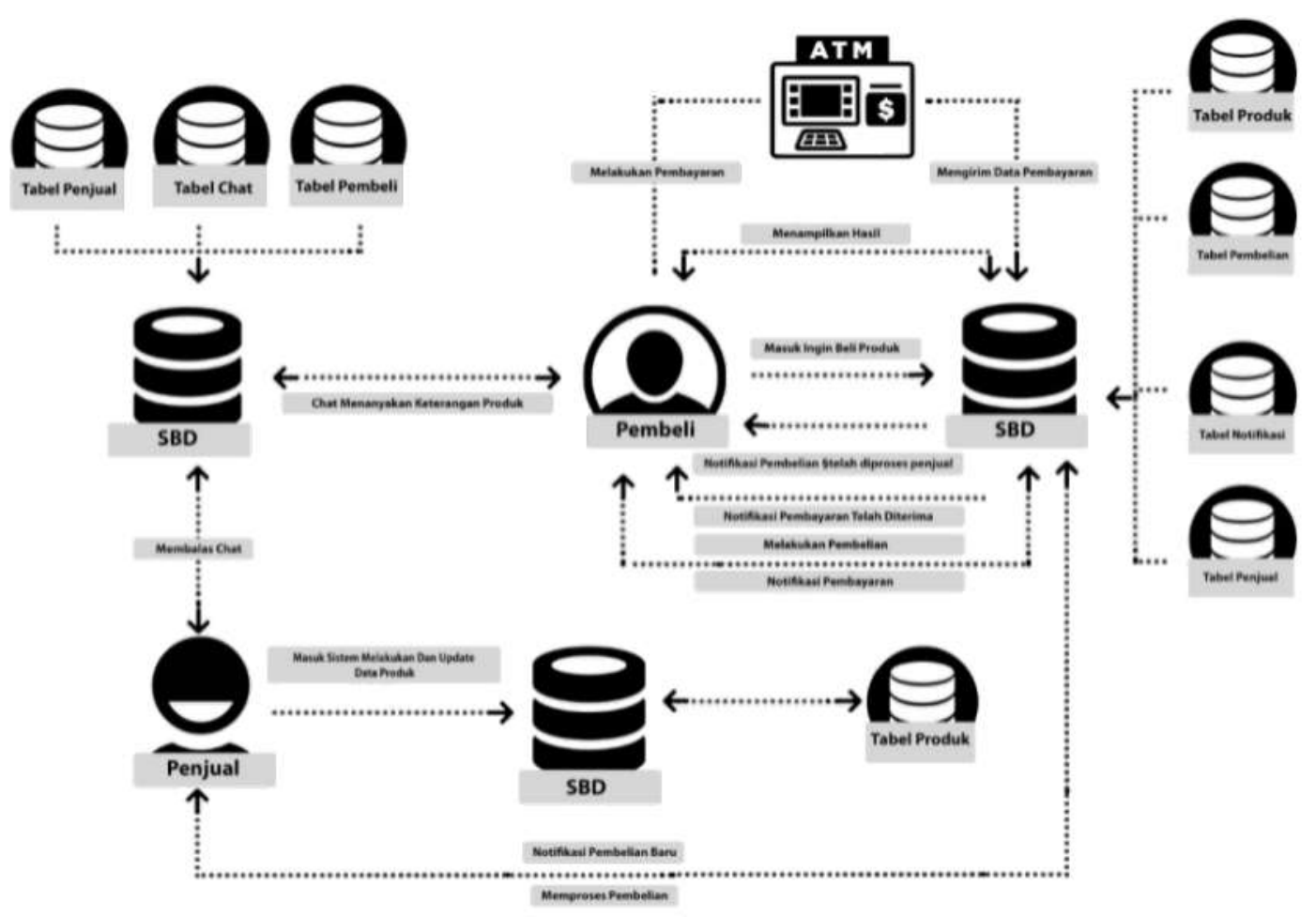

Gambar 10. Rule penjual terajin

Untuk menentukan seorang penjual bisa dikategorikan penjual terajin, maka harus memenuhi aturan yang sudah ditetapkan yaitu, jumlah produk yang dijual dan seberapa responsif terhadap request atau seberapa respon terhadap pesanan maupun chat yang masuk. Dalam penentuan penjual terajin maka sistem akan mengakses sebanyak 7 (tujuh) tabel pada sistem database Bukadagang. 
Dengan diberi predikat penjual terajin maka seorang penjual akan mendapatkan reward dari Bukadagang berupa produknya akan menempati tempat teratas dalam pencarian pada sistem bukadang.

Untuk menjadi seorang penjual terajin, maka seorang penjual atau pedagang pada sistem Bukadagang harus memenuhi kriteria seperti pada Gambar 10.

Rule penjual terajin adalah visualisasi dari alur penentuan penjual terajin, adapun tabel yang berperan sebagai berikut:

1) Dalam proses pembelian produk tabel yang berperan adalah tabel produk, tabel pembelian, tabelnotifikasi, tabel penjual

2) Untuk Update data produk tabel yang berperan adalah tabel produk

3) Untuk keterangan produk dan chat tabel yang berperan adalah tabel penjual, tabel pembeli, dan tabel chat

Untuk Query penentuan penjual terajin, maka harus mengeksekusi view-view dalam perintah $S Q L$ sudah dibuat sebelumnya, dimana view-view itu yang nantinya akan menjadi penentu seorang dikatakan penjual terajin berikut Query $S Q L$ yang berperan untuk menentukan penjual terajin, dan hasil dari penggunaan Query terlihat pada Gambar 11. Gambar 12 merupakan rancangan interface untuk tampilan Bukadagang dengan menggunakan Query di bawah ini.

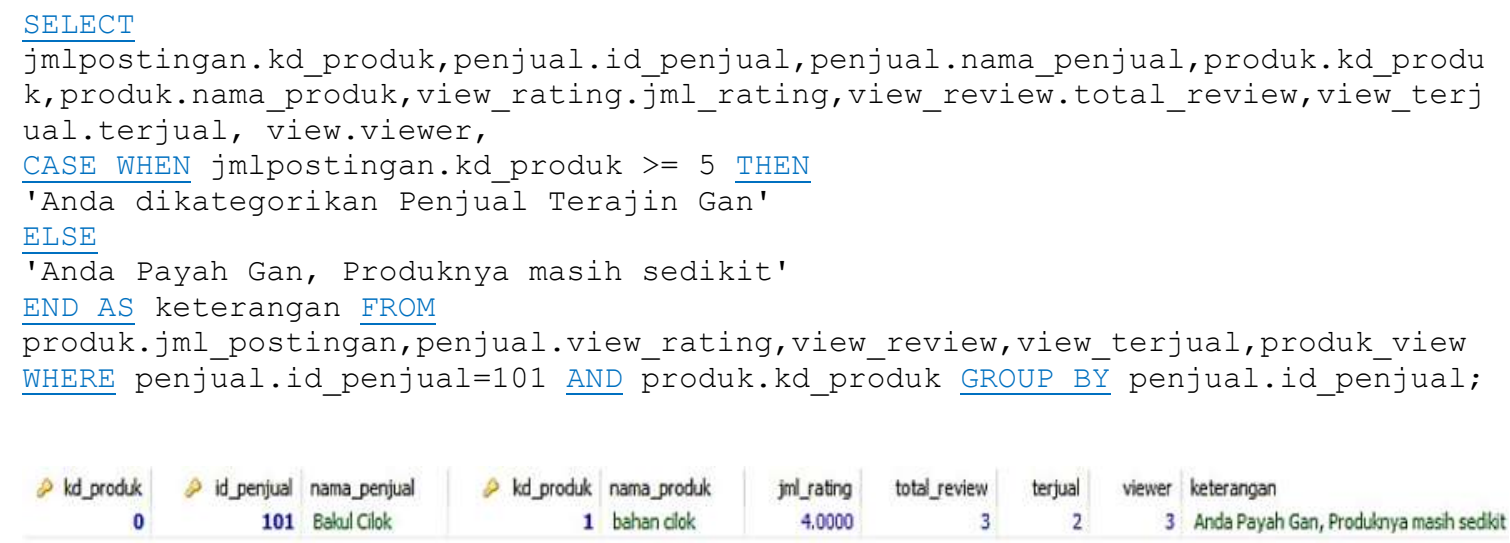

Gambar 11. Hasil Query Penjual Terajin
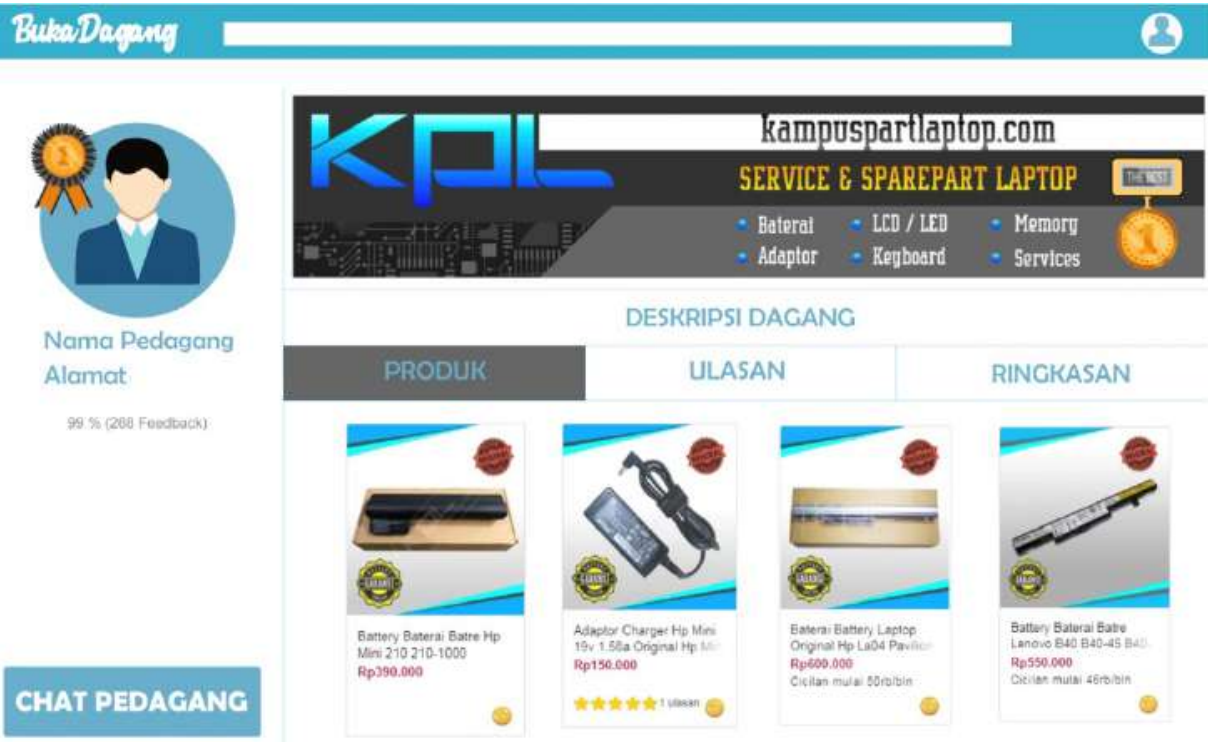

Gambar 12. Rancangan Interface Penjual Terajin 
Seorang penjual yang dikategorikan sebagai penjual terajin akan diberikan reward berupa produknya akan menempati tempat teratas dalam pencarian produk dalam Bukadagang, dengan pemberian reward ini diharapkan akan memotivasi para penjual atau pedagang untuk meningkat kualitas penjualannya, dengan demikian akan menyebabkan semakin banyak user atau penjual yang akan menggunakan Bukadagang untuk bertransaksi, dengan semakin banyaknya transaksi pada sistem Bukadagang tentu akan memberikan feedback atau keuntungan kepada pihak Bukadagang.

\subsection{Diskon}

Diskon merupakan salah satu item yang sangat penting dalam sistem Bukadagang, dimana sistem pemberian diskon pada Bukadagang di bagi menjadi 2 (dua) yaitu diskon kuantitif dimana diskon ini akan diberikan setiap minggu atau setiap bulan tergantung banyaknya peminat terhadap sebuah produk, sedangkan untuk diskon musiman akan diberikan setiap perayaan hari raya keagamaan dan tahun baru.

Dalam menentukan diskon sistem Bukadagang hanya menggunakan 1 (satu) parameter yaitu seberapa banyak peminat calon pembeli terhadap sebuah produk dan pelaksanaan hari raya keagamaan dan tahun baru. Tabel yang bekerja pada penentuan diskon adalah tabel viewer dan tabel produk. Rule dalam pemberian diskon pada sistem Bukadagang terlihat pada Gambar 13.

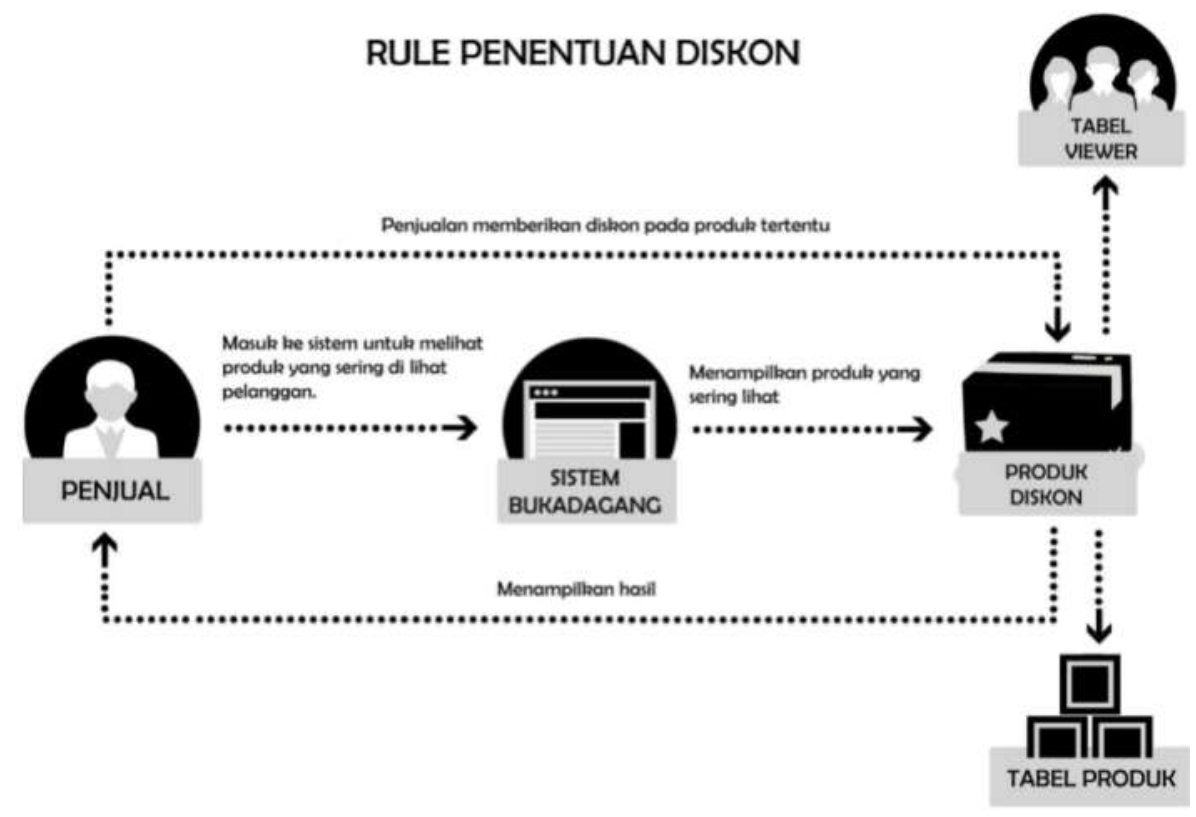

Gambar 13. Rule Pemberian diskon

Untuk Query penentuan diskon, maka harus dibuatkan view-view dalam perintah SQL, dalam pemberian diskon hanya menggunakan 1 (satu) parameter yaitu banyaknya peminat terhadap sebuah produk. Gambar 14 merupakan hasil eksekusi dari perintah SQL untuk diskon.

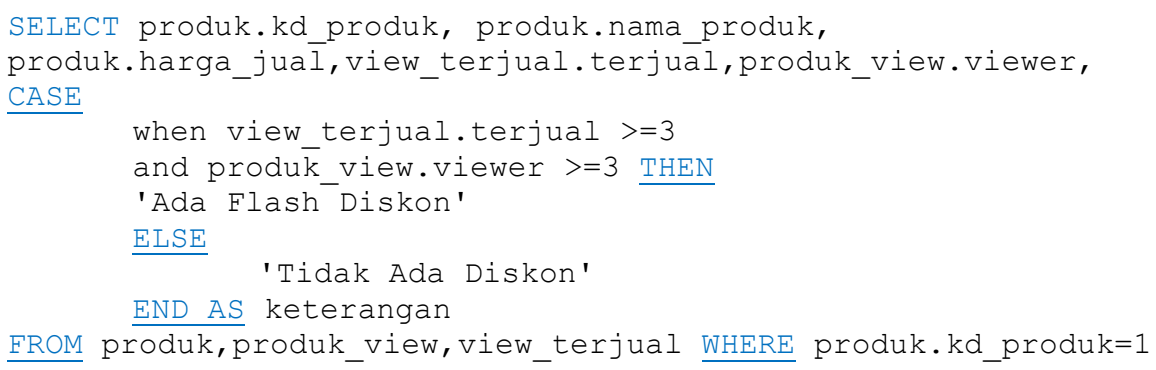




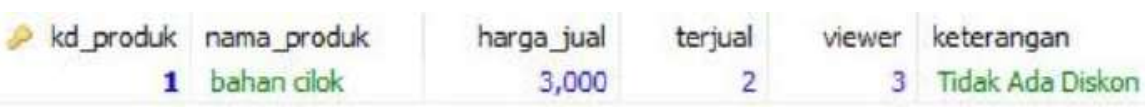

Gambar 14. Hasil Query Diskon

\section{KESIMPULAN}

Berdasarkan hasil analisis yang telah dilakukan terhadap faktor-faktor yang akan mempengaruhi eksistensi Platform Bukadagang, maka dapat ditarik kesimpulan sebagai berikut:

1. Semua tabel pada database Platform Bukadagang sudah menggunakan constrains seperti primary key dan foreign key untuk table yang memiliki relasi.

2. Tiga faktor utama yang akan mempengaruhi eksistensi platform Bukadagang ditengah persaingan Platform- Platform E-Commerce saat ini, yaitu Produk Populer, Penjual Terajin dan penentuan Diskon untuk setiap produk.

3. Analisis terhadap 3 (tiga) faktor atau item yang menjadi faktor utama eksistensi Platform Bukadagang yaitu Produk Populer, Penjual Terajin dan Diskon dapat memberikan gambaran bagaimana sistem pada Platform Bukadagang bekerja, baik dari sisi aturan-aturan atau rulerule di setiap item maupun dari sisi perancangan dan pemanfaatan database nya.

4. Pemanfaatan dan penggunaan teknologi internet diharapkan dapat memberikan manfaat yang besar terhadap pertumbuhan E-Commerce dan ekonomi digital di Indonesia dan perusahaan yang mampu bersaing dalam kompetisi tersebut adalah perusahaan yang terus melakukan inovasi-inovasi baru dan mampu implementasikan inovasi tersebut untuk keberlanjutan bisnis.

\section{SARAN}

Dari keseluruhan pemaparan pada analisis ini maka didapatkan kekurangan yang menjadi saran untuk penulisan pada penelitian berikutnya:

1. Implementasi prototype Platform Bukadagang dalam sebuah sistem yang bisa di gunakan oleh masyarakat umum.

2. Menjelaskan pemanfaatan dan cara komunikasi data dengan API pihak ketiga (Third Party).

3. Menjelaskan lebih detail terhadap ulasan yang diberikan pembeli terhadap sebuah produk dengan pendekatan analisis sentimen dan stemming untuk menentukan presentasi ulasan positif dan negatif calon pembeli terhadap sebuah produk.

\section{DAFTAR PUSTAKA}

[1] Das, K., Gryseels, M., Sudhir, P., Tan, K. T., 2016, Unlocking Indonesia's digital opportunity, McKinsey Indonesia Office.

[2] Sandy, K., 2015, Penerapan Rapid Application Development Dalam Sistem Perniagaan Elektronik Furniture, Citec Journal, No. 4, Vol. 2, Hal. 265-276

[3] Pujastuti, E., Winarno, W. W., Sudarmawan., 2014, Pengaruh E-Commerce Toko Online Fashion Terhadap Kepercayaan Konsumen, Citec Journal, No.2, Vol. 1, Hal. 139-153

[4] Irmawati, D., 2011, Pemanfaatan E-Commerce Dalam Dunia Bisnis, Jurnal Ilmiah Orasi Bisnis, Vol. VII, Hal. 95-112

[5] Abidin, Z., 2007, Analisis Eksistensial, Raja Grafindo Persad, Jakarta 
Citec Journal, Vol. 5, No. 3, Mei 2018 - Juli 2018

ISSN: 2460-4259

[6] Larasati, A., 2017, Mengenal Platform e-Commerce di Era Digital, https://medium.com/@larasatisyifa/mengenal-platform-e-commerce-di-era-digital6275dlea0e78, diakses tgl 4 Januari 2019.

[7] Arikunto, S., 2005, Manajemen Penelitia Edisi Revisi, Rineka Cipta, Jakarta

[8] Sugiyono, 2011, Metode Penelitian Kuantitatif Kualitatif Dan R\&D, Alfabeta, Bandung.

[9] Faisal, S., 1990, Penelitian Kualitatif (dasar-dasar dan aplikasi), YA3 Malang, Malang. 